\title{
"SHOULD I SPEAK IN ENGLISH ALL THE TIME?": TEACHER'S TALK PADA PENGENALAN BAHASA INGGRIS BAGI ANAK USIA DINI
}

\author{
Winti Ananthia ${ }^{1}$
}

\begin{abstract}
ABSTRAK
Ditengah anjuran bagi guru untuk selalu menggunakan bahasa Inggris selama pembelajaran, guru seringkali merasa tidak nyaman tentang hal ini. Ketidaknyamanan ini dapat disebabkan koleh berbagai faktor. Faktor pertama dapat disebabkab karena guru memiliki kemampuan bahasa Inggris yang terbatas. Faktor berikutnya dapat juga karena kemampuan bahasa Inggris anak yang masih sangat terbatas. Faktor ini membuat guru khawatir anak tidak dapat memahami guru ketika guru menggunakan bahasa Inggris. Sumber utama input bahasa dalam proses pembelajaran adalah teacher's talk yang dihasilkan guru. Artikel ini membahas peranan serta fungsi teacher's talk dalam proses pengenalan bahasa Inggris bagi anak usia dini. Dibahas pula tentang bahaimana karakteristik anak sebagai pembelajar bahasa, penggunaan bahasa Inggris sebagai bahasa pengantar pada pengenalan bahasa Inggris bagi anak usia dini. Artikel ini juga membahas mengenai boleh atau tidaknya penggunaan bahasa Indonesia dalam proses pengenalan dan pembelajaran bahasa Inggris untuk anak usia dini.
\end{abstract}

\section{A. PENDAHULUAN}

Pentingnya penguasaan bahasa Inggris sebagai salah satu tolak ukur keberhasilan seseorang semakin dirasakan di negara-negara non-berbahasa Inggris (Brewster, Ellis \& Girard, 2002). Hal ini merupakan salah satu faktor yang membuat semakin meluasnya kebutuhan akan pembelajaran bahasa Inggris sebagai bahasa asing, atau yang sering disebut sebagai English as a Foreign Language (EFL), di Indonesia. Bahasa Inggris yang pada awalnya mulai dibelajarkan pada tingkat sekolah menengah pertama, saat ini mulai dibelajarkan di tingkat pendidikan yang lebih rendah, yaitu sekolah dasar. Bahkan banyak pula yang memulai mengenalkan bahasa Inggris di tingkat Pendidikan Anak Usia di Dini (PAUD), yaitu Taman Kanak-kanak (TK) ataupun kelompok bermain (preschool) (Yuliariatiningsih, Ananthia, \& Yanthi, 2013).

Pada umumnya, lembaga PAUD memperkenalkan bahasa Inggris pada anak usia dini berdasarkan permintaan orang tua yang menginginkan putra-putrinya memiliki kecakapan berbahasa asing. Selain itu, di kota Bandung terdapat program pemerintah kota yang disebut "Kamis Inggris", yang merekomendasikan semua institusi di kota ini untuk menggunakan bahasa Inggris pada hari tersebut. Hal ini disambut baik oleh sejumlah TK di Bandung untuk mengenalkan bahasa Inggris pada anak-anak di hari tersebut (Ananthia, Harun \& Silawati, 2015).

Sayangnya, seringkali program pengenalan bahasa Inggris pada anak usia dini berjalan kurang bermakna. Hal ini terjadi karena proses pengenalan bahasa

${ }^{1}$ Dosen Kampus UPI Cibiru 
Inggris di TK hanya berupa penggunaan kosakata bahasa Inggris yang terpisah dari konteksnya, yang disertai terjemahan dalam bahasa Indonesia (Yuliariatiningsih, dkk., 2013; Ananthia, dkk., 2015). Sehingga penggunaan bahasa Inggris hanyalah memorisasi dari translasi kata-kata dalam bahasa Indonesia. Penyebab terjadinya hal demikian dikarenakan persepsi guru yang menganggap belajar bahasa asing sebagai hal yang sulit bagi usia dini (Ananthia, dkk., 2015) dan kemampuan guru yang terbatas dalam membelajarkan bahasa Inggris sebagai bahasa asing bagi anak usia dini (Moon, 2005).

Walaupun penggunaan bahasa Inggris di Indonesia banyak dijumpai (misalnya pada film, penamaan tempat, menu makanan, dan iklan pada papan iklan), namun, bahasa Inggris di Indonesia tidak memegang peranan sebagai bahasa nasional ataupun bahasa kedua. Di Indonesia bahasa Inggris berperan sebagai bahasa asing, dimana bahasa tersebut tidak digunakan sebagai bahasa resmi negara maupun percakapan sehari-hari bagi sebagian besar warganya (Ananthia, 2010; Paul, 2007, hlm.1). Oleh karenanya, pembelajar bahasa Inggris di Indonesia disebut sebagai pembelajar bahasa Inggris sebagai bahasa asing ( $E F L$ learners). Tidak seperti pembelajar bahasa Inggris sebagai bahasa kedua, EFL learners biasanya sulit sekali untuk mendapatkan exposure bahasa Inggris yang natural (Paul, 2007, hlm. 2; Brewster, et al., 2002) pada kehidupan sehari-hari. Oleh karena itu, input bahasa yang didapat para pembelajar bahasa asing sangat tergantung dari apa yang diperoleh dari guru di kelas selama pembelajaran (Brewster, et al., 2002) dalam bentuk teacher's talk.

Teacher's talk merupakan sumber bahasa yang paling utama dalam pembelajaran bahasa Inggris sebagai bahasa asing (Pinter, 2006). Sayangnya, tidak semua guru menyadari pentingnya teacher's talk bagi perkembangan bahasa Inggris para pembelajar EFL. Sehingga hal ini membuat guru tidak memanfaatkan momen penting dengan menggunakan bahasa Inggris semaksimal mungkin selama proses pembelajaran. Artikel ini mencoba untuk membahas peranan serta fungsi teacher's talk dalam proses pengenalan bahasa Inggris bagi anak usia dini. Dibahas pula tentang penggunaan bahasa Inggris sebagai bahasa pengantar pada pengenalan bahasa Inggris bagi anak usia dini. Artikel ini juga membahas mengenai boleh atau tidaknya penggunaan bahasa Indonesia dalam proses pengenalan dan pembelajaran bahasa Inggris untuk anak usia dini.

\section{B. PEMBAHASAN}

\section{Anak-anak Sebagai Pembelajar Bahasa}

Fakta menunjukkan bahwa anak adalah pembelajar bahasa yang sukses ketika belajar bahasa pertama (Brewster et al., 2002; Moon, 2005; Paul, 2007; Pinter, 2006). Secara umum, pada proses pemerolehan bahasa, anak-anak melewati setidaknya lima tahapan dalam kemampuan berbahasa (Wells, dalam Brewster, et al., 2002, hlm.15-16):

1. Ujaran awal berupa kalimat kalimat sederhana yang berfungsi untuk menarik perhatian orang dewasa di sekitarnya, mendapatkan apa yang diinginkan. 
Dengan sumber bahasa yang sangat terbatas, makna ditentukan dari intonasi yang dihasilkan. Contohnya: "Mama, susu".

2. Anak-anak mulai memberikan penamaan dan mengklasifikasikan bendabenda, bertanya dengan kata tanya "dimana?" atau "apa itu?". Selain itu, juga mulai dapat menyebutkan perpindahan lokasi, seperti: "naik", "turun", beberapa kata sifat sederhana, seperti: "panas", "dingin”, "besar', "kecil”, juga penggunaan kata kepunyaan, seperti: "tasnya ayah".

3. Anak-anak mulai dapat memberikan berbagai jenis pertanyaan dengan bentuk kalimat pernyataan yang dimodifikasi dengan intonasi untuk kalimat tanya, seperti: "Ade pe[r]gi, Mama?". Mereka juga mulai dapat mengutarakan keinginan mereka yang mulai kompleks dengan mengatakan, "aku mau...", menceritakan kejadian di masa lampau dan kejadian yang sedang berlangsung.

4. Pada tahapan ini anak-anak sudak mulai dapat menggunakan struktur kalimat yang lebih kompleks dalam mengekspresikan permintaan, menjelaskan sesuatu, dan meminta penjelasan atas sesuatu dengan mengatakan "kenapa sih...?".

5. Pada tahapan ini, anak sudah dapat menggunakan bahasa dengan berbagai cara yang lebih kompleks lagi untuk mendapatkan informasi, bertanya dan menjawab berbagai jenis pertanyaan, memberikan saran, menawarkan bantuan, mengutarakan keinginan, dan mengekspresikan perasaan. Pada tahapan ini, anak sudah dapat mulai menjelaskan suatu sebab akibat dan juga memahami bahwa suatu peristiwa bersifat rutinitas, berulang-ulang, maupun baru dimulai.

Secara umum anak-anak melalui lima tahapan tersebut, walaupun setiap anak melewatinya dalam usia yang berbeda-beda, namun biasanya lima tahapan tersebut terlewati semelum mereka mencapai usia sekolah (Wells, dalam Brewster, et al., 2001, hlm. 15). Dengan mengetahui tahapan tersebut, pendidik PAUD akan mendapatkan gambaran yang bermanfaat mengenai perkembangan konseptual anak-anak yang seyogianya disesuaikan dengan program pengenalan bahasa asing bagi anak usia dini.

Selain mengetahui tahapan perkembangan bahasa anak, tentunya pendidik juga perlu mengetahui dan memahami karakteristik anak usia dini yang secara langsung maupun tidak langsung akan mempengaruhi proses pengenalan dan pembelajaran bahasa Inggris sebagai bahasa asing. Karakteristik anak usia dini tersebut antara lain adalah bahwa mereka sangat aktif secara fisik (Brewster et al., 2002, hlm. 27; Scott \& Ytreberg, 2003). Hal tersebut membuat aktivitas yang dilakukan dalam proses pembelajaran hendaknya melibatkan pergerakan fisik siswa secara aktif (Moon, 2005). Namun demikian, Halliwell (1994, hlm. 21) mengingatkan para pendidik untuk menjaga keseimbangan antara kegiatan stiring dan settling; yaitu mana kegiatan yang melibatkan fisik anak secara aktif, mana kegiatan yang memerlukan pelibatan pikiran tanpa fisik yang aktif.

Selain itu, pendidik juga seyogianya memahami bahwa anak memiliki sifat yang cenderung mudah bosan (Brewster et al., 2002, hlm. 27; Scott \& Ytreberg, 2003) dan mudah terdistraksi oleh gangguan yang kecil sekalipun (Brewster et al., 
2002, hlm. 28). Namun, ketika suatu aktivitas sesuai dengan apa yang mereka sukai, mereka dapat fokus untuk waktu yang cukup lama (Brewster et al., 2002, hlm. 28). Karakteristik anak usia dini berikutnya adalah bahwa mereka masih berada pada tahap literasi dini (Brewster et al., 2002, hlm.27). Hal ini berarti bahwa anak-anak mesih berada pada tahap awal perkembangan bahasa pertama mereka. Oleh karena itu, belajar bahasa Inggris sebaiknya memberikan proporsi yang lebih untuk kegiatan oral (listening dan speaking), dibandingkan kegiatan yang melibatkan tulisan (reading dan writing) (Phillips, 1993). Lebih lanjut, Brewster et al., (2002) menekankan bahwa anak-anak sebaiknya diberikan kesempatan untuk menyimak dalam waktu yang cukup lama sebelum mereka dituntut untuk berbicara (hlm. 26). Kegiatan reading dan writing hanya dapat dilakukan setelah anak-anak mendapat kesempatan mengembangkan keterampilan listening dan speaking (Brewster, et al., 2002, hlm. 26; Linse, 2005; Pinter, 2006, hlm. 45).

Selanjutnya, hal yang sangat menjadi ciri khas karakteristik anak yaitu insting anak untuk bermain dan bersenang-senang (Halliwell, 1994, hlm. 6; Brewster et al., 2002, hlm. 27; Moon, 2005, hlm 6-7; Pinter, 2006, hlm.2). Para pendidik sebaiknya tidak mengesampingkan karakteristik anak-anak yang satu ini. Ketika pembelajaran dimulai, bukan berati anak-anak diminta berhenti dari dunia bermainnya. Akan tetapi sebaiknya segala kegiatan dalam proses belajar anak dapat terintegrasi dengan dunia bermain anak-anak.

\section{Pengenalan Bahasa Inggris pada Anak Usia Dini}

Ada hal yang mendasar yang membedakan pembelajaran bahasa Inggris sebagai bahasa asing untuk anak usia dini dan untuk pembelajar dewasa. Anak usia dini tidak memiliki motivasi yang datang dari diri mereka sendiri tentang alasan mereka belajar bahasa Inggris (Halliwell, 1994; Brewster et al., 2002; Moon, 2005; Pinter, 2006). Pada umumnya alasan mengapa anak usia dini di Indonesia belajar bahasa Inggris sebagai bahasa asing karena keinginan orang tua mereka (Harun, Yuliariatiningsih, Ananthia, \& Yanthi, 2014; Yuliariatiningsih, dkk., 2013, hlm. 104). Oleh karena itu, kegiatan dalam pengenalan bahasa Inggris untuk anak usia dini sebaiknya yang benar-benar dapat membuat anak terlibat secara aktif berdasarkan fitrah mereka sebagai anak-anak.

Ketika belajar bahasa asing, anak-anak tidak datang dengan tangan kosong. Anak-anak telah dibekali seperangkat insting, keterampilan dan karakteristik yang dapat membantu mereka belajar bahasa asing (Halliwell, 1994, hlm. 3). Anakanak juga telah dilengkapi pengalaman bahasa yang mereka bawa dari luar kelas dan kemampuan alami lain yang dapat membantu (juga menghambat) proses mereka belajar bahasa asing (Moon, 2005). Berikut ini dijelaskan dua diantaranya.

Anak dibekali kemampuan untuk menangkap makna tanpa harus memahami arti kata per kata (Wright, 1995). Anak-anak sangat sensitif akan petunjuk sekecil apapun untuk memahami bahasa. Intonasi, ekspresi wajah, gerakan tubuh dan situasi sekitar dapat membantu anak dalam memahami pesan sesuai dengan konteks yang berlaku (Halliwell, 1994). Mereka memiliki kemampuan untuk menginterpretasi pesan dari pentujuk yang didapatkan tanpa perlu tahu arti setiap kata yang diucapkan. Oleh karena itu, seorang pendidik perlu untuk membantu 
anak dengan memberikan petunjuk-petunjuk melalui gestur, intonasi, gerak tubuh, mimik wajah serta demonstrasi untuk menyampaikan pesan dalam bahasa target (Phillips, 1993). Hal ini juga disepakati oleh Moon (2005) yang menegaskan bahwa anak akan cenderung untuk mendapatkan meaning dibandingkan form suatu bentuk tuturan. Hal ini sekaligus mengingatkan para pendidik untuk tidak terlalu fokus terhadap struktur bahasa pada awal pembelajaran bahasa, namun untuk lebih fokus terhadap makna sebuah ujaran (Moon, 2005, hlm. 5).

Selanjutnya, anak memiliki kemampuan untuk menggunakan bahasa yang terbatas yang mereka miliki untuk kemudian mereka gunakan secara kreatif. Anak senantiasa melakukan melakukan pengamatan, analogi, penggabungan dan perbandingan selama mendapatkan input bahasa. Mereka dapat memproduksi bahasa secara kreatif yang bahkan belum pernah mereka dengar sebelumnya. Moon (2005, hlm. 4) memberikan contoh untuk hal ini, ketika seorang anak menyebutkan "the flower's stick" dengan maksud untuk mengatakan batang bunga yang dalam bahasa Inggris adalah "stem". Kata "stem" mungkin belum dikenal sebelumnya, namun anak tersebut dapat dengan kreatif mengkombinasikan kata-kata yang telah dikenal untuk mengungkapkan maksudnya. Contoh lain juga dikemukakan oleh Halliwell (1994, hlm. 4) ketika anak mengatakan "don't unring” ketika meminta seorang penelepon untuk tidak memutuskan sambungan telepon. Ujaran tersebut sebetulnya tidak lazim dalam bahasa Inggris. Anak mendapatkan istilah itu berdasarkan pengetahuannya bahwa kata "ring" merupakan kata kerja untuk 'menelepon'. Jika ditambah awalan "un" maka akan menegasikan makna kata. Sehingga jika ditambah kata negatif "don't" di awal kata sebelumnya dapat bermakna "jangan tutup teleponnya".

Kemampuan anak untuk menggunakan bahasa secara kreatif juga tercermin dari kesalahan yang dibuat. Misalnya ketika anak mengatakan "I goed to a supermarket with my mum yesterday". Dari kalimat tersebut dapat diketahui bahwa anak telah memahami ada perubahan bentuk kata kerja lampau dalam bahasa Inggris. Pada kata kerja regular, biasanya perubahan bentuk tersebut ditandai dengan penambahan ' $d$ ' atau '-ed' diakhir kata. Padahal aturan tersebut tidak berlaku untuk irregular verbs. Moon (2005) menegaskan bahwa kesalahan yang dibuat anak pada proses belajar membuktikan bahwa anak tidak hanya 'membeo' atau mengimitasi selama input bahasa, namun juga terjadi proses belajar aktif, yaitu mencoba-coba bagaimana sistem suatu bahasa bekerja (hlm 1).

Pada proses belajar bahasa, anak usia dini akan merespon bahasa berdasarkan apa yang mereka dapat lakukan dengan bahasa tersebut. Hal tersebut berbeda dengan cara pandang orang dewasa yang cenderung lebih memerhatikan sistem abstrak dari suatu bahasa (aturan gramatika) (Phillips, 1993). Implikasinya adalah bahwa pembelajaran bahasa Inggris untuk anak usia dini seyogianya menyenangkan dan dapat memberikan stimulasi pengalaman berbahasa pada anak. Dengan demikian, kegiatan sebaiknya dirancang sesederhana mungkin agar anak memahami apa yang guru harapkan mereka dapat lakukan (Halliwell, 1994; Phillips, 1993). Kegiatan untuk anak usia dini juga haru sesuai dengan kemampuan mereka, yaitu, tidak terlalu mudah, juga tidak terlalu sukar yang lebih menitikberatkan pada kegiatan oral (Phillips, 1993, hlm. 5) dan melibatkan pergerakan fisik (Halliwell, 1994; Linse, 2005). Kegiatan yang sesuai untuk anak 
usia dini diantaranya adalah songs (Linse, 2005; Pinter, 2006), games (Lewis \& Bedson, 2004; Paul, 2007), simple storytelling (Brewster et al., 2002; Wright, 1995; Phillips, 1993), total physical response yang melibatkan kegiatan mewarnai, menggunting, dan menempel (Linse, 2005; Moon, 2005; Phillips, 1993).

Lebih lanjut, Moon (2005) mengutarakan bahwa situasi belajar bahasa bagi anak seyogianya dapat menciptakan keinginan dan kebutuhan riil untuk berbahasa Inggris. Selain itu, pembelajaran bahasa Inggris sebaiknya dapat menyediakan alokasi waktu yang memadai untuk penggunaan bahasa Inggris, memberikan exposure yang bervariasi dan input bermakna yang fokus terhadap komunikasi. Pembelajaran EFL juga diharapkan dapat memberikan kesempatan pada anak untuk bereksperimen dengan bahasa yang baru dipelajarinya dengan memberikan kesempatan untuk berlatih bahasa dalam berbagai konteks. Situasi yang menyenangkan juga sangat diharapkan dapat muncul dari proses pembelajaran bahasa, sehingga guru dapat memberikan umpan balik dalam situasi yang santai dan tidak menakutkan. Dengan demikian, diharapkan anak dapat memahami secara tidak langsung pola yang ada dalam bahasa target (Halliwell, 1994; Moon, 2005).

\section{Teacher's Talk pada Pembelajaran Bahasa Asing}

Seperti telah diutarakan sebelumnya bahwa guru adalah sumber utama input bahasa bagi anak balajar bahasa asing (Pinter, 2006). Pernyataan tersebut sangat sesuai dengan konteks di Indonesia, dimana anak pada umumnya hanya mendapatkan exposure pada bahasa Inggris di dalam kelas pembelajaran bahasa Inggris. Oleh karenanya, sumber utama input bahasa Inggris bagi anak-anak adalah ketika guru berbicara, bernyanyi, mendongeng, berdialog dalam dramatisasi, dan saat memberikan instruksi. Teacher's talk membantu anak untuk terbiasa dengan pola intonasi dan bunyi-bunyi yang ada pada bahasa target (Pinter, 2006, hlm. 47).

Lebih lanjut, Moon (2005, hlm. 61) mengungkapkan fungsi teacher's talk, yaitu untuk: memberikan instruksi, mengontrol/mendisiplinkan kelas, memberikan umpan balik, memuji, mencari informasi, memberikan contoh penggunaan bahasa Inggris, mengecek pemahaman anak, berkelakar, dan untuk menjaga suasana agar menyenangkan. Guru dapat memilih diantara fungsi-fungsi teacher's talk tersebut, mana yang disampaikan dalam bahasa Inggris dan mana yang disampaikan dalam bahas Indonesia. Jika guru memilih untuk hanya menggunakan bahasa Inggris ketika mengontrol kelas, memberikan informasi, memberikan contoh, dan mengetes anak, maka dalam situasi tersebut hanya hubungan guru - anak akan sangat formal dan pihak guru akan mendapatkan porsi yang sangat besar untuk berbicara di kelas. Dengan demikian jika seorang guru membatasi pemberian input bahasa Inggris hanya sebatas pemberian penjelasan dan contoh penggunaan bahasa, tidak untuk fungsi lainnya seperti berkelakar dan memberikan instruksi, maka guru hanya menyediakan input bahasa yang sangat terbatas (Moon, 2005, hlm 62) yang mungkin akan membatasi perkembangan bahasa Inggris anak. Pembahasan mengenai berbagai pertimbangan tentang 
penggunaan bahasa Indonesia atau bahasa Inggris sebagai bahasa pengantar di kelas EFL dijelaskan pada bagian selanjutnya.

\section{Bahasa Inggris Versus Bahasa Indonesia: Penggunaan Bahasa Pengantar di Kelas EFL Bagi Anak Usia Dini}

Bahasa apa yang digunakan guru selama pembelajaran EFL akan sangat bergantung pada anggapan guru mengenai bagaimana anak belajar bahasa asing (Moon, 2005, hlm.3). Ketika guru beranggapan bahwa ketika anak belajar bahasa asing sama prosesnya seperti anak belajar bahasa pertama, maka guru akan menyiapkan aktivitas belajar bahasa yang dapat mengeksplorasi kemampuan alami anak untuk berbahasa dalam komunikasi. Sedangkan di sisi lain, jika guru beranggapan bahwa anak belajar bahasa asing dengan mengetahui terjemahan kata/kalimat dalam bahasa pertamanya, maka guru akan selalu melakukan translasi selama proses pembelajaran bahasa asing. Perhatikan percakapan antara guru (G) dan anak (A) berikut ini:

G: Anak-anak, coba lihat apa yang ibu guru bawa?

A: Balon!

G: Iya, pintar sekali... Warna apa saja ya balonnya?

A: Merah, kuning, hijau, biru, oranye... (anak-anak menyebutkan warna-warna balon bersamaan).

G: Iya betul. Anak-anak, kalau merah bahasa Inggrisnya apa?

A: Red, bu guru.

G: Iya, pintar sekali.

Percakapan tersebut diambil pada saat program pengenalan bahasa Inggris bagi anak usia dini. Jika diperhatikan, teacher's talk yang diproduksi guru sepenuhnya dalam bahasa Indonesia. Anak-anak dapat memproduksi kata 'merah' dalam bahasa Inggris setelah sebelumnya diberi latihan menerjemahkan warna-warna ke dalam bahasa Inggris.

Ketika anak memasuki kelas EFL, itu berarti mereka memasuki dunia 'bahasa Inggris' yang berarti guru seyogianya telah siap dengan setting dalam bahasa Inggris, termasuk teacher's talk yang akan disampaikan pada anak (Brewster et al., 2002; Paul, 2007; Phillips, 1993). Akan tetapi, banyak hal yang menjadi pertimbangan alasan guru menggunakan bahasa Indonesia di kelas EFL.

Walaupun penggunaan bahasa Inggris selama proses belajar EFL sangat disarankan, Moon (2005, hlm. 63) mengingatkan para guru akan keunggulan dan kelemahan penggunaan bahasa Inggris yang perlu diantisipasi. Penggunaan teacher's talk dalam bahasa Inggris akan meningkatkan exposure bahasa Inggris yang diterima anak. Akan tetapi, hal tersebut akan membuat guru memerlukan waktu yang lebih panjang hanya untuk menyampaikan sesuatu yang sederhana, yang dapat membuat anak yang telah bersemangat belajar menjadi kehilangan semangat dan konsentrasi. Hal itu juga akan berdampak pada penyelesaian rencana pembelajaran/silabus yang lebih panjang. Berikutnya, walaupun penggunaan bahasa Inggris yang maksimal dapat mengembangkan rasa percaya diri anak dalam penggunaan bahasa target, namun bagi anak yang agak lambat dapat membuat mereka semakin takut untuk mencoba berkomunikasi dalam bahasa Inggris. 
Lebih lanjut Moon (2005) mengutarakan bahwa walaupun ketika guru menyadari bahwa penggunaan teacher's talk dalam bahasa Inggris dapat memberikan alasan yang riil pada anak mengapa berbahasa Inggris diperlukan, namun guru seringkali terkendala pada kemampuan bahasa Inggris yang terbatas. Untuk hal ini, Moon (2005) menyarankan guru untuk selalu meningkatkan kemampuan berbahasa Inggris dengan mengikuti kursus bahasa Inggris dan terus berlatih menyampaikan teacher's talk dalam bahasa Inggris.

Selain itu, Moon (2005) juga telah mengidentifikasi kendala yang dihadapi guru ketika ingin menerapkan teacher's talk dalam bahasa Inggris, diantaranya ketika guru kesulitan membuat anak paham akan apa yang dikatakan. Jika hal tersebut terjadi, guru disarankan untuk menuliskan apa saja yang hendak disampaikan pada anak, agar guru dapat tetap fokus untuk dapat untuk menyampaikannya sesederhana mungkin. Guru juga disarankan untuk merekam dan menganalisis teacher's talk agar dapat mengidentifikasi dan merevisi ketika teacher's talk mereka terlalu kompleks. Selain itu, guru disarankan untuk saling belajar dan memberi masukan dengan sesama guru.

Terkadang guru juga terlalu mudah menyerah ketika anak meminta guru untuk berbicara dalam bahasa pertama (Moon, 2005, hlm. 73). Menghadapi kondisi ini, sebaiknya guru dapat menyampaikan pada anak alasan mengapa bahasa Inggris sebaiknya digunakan selama proses pembelajaran. Guru bersama anak dapat melakukan persetujuan tentang kapan bahasa Inggris wajib digunakan. Untuk mengatasi hal ini, sesekali guru dapat pula mengundang native speaker jika itu memungkinkan.

Untuk memaksimalkan penggunaan bahasa Inggris ditengah keterbatasan bahasa, guru dapat menyiasatinya dengan membiasakan berbagai ungkapan sederhana dalam bahasa Inggris, misalnya ekspresi sederhana seperti 'good morning', 'thank you', 'I'm sorry', 'goodbye', 'see you next week'; meminta bantuan seperti 'how do I say ... in English?', What's this in English?; instruksi guru seperti 'please stand up', 'let's play', 'be quiet', 'it's break time'; dan ujaran sederhana antar anak seperti 'can I borrow your ...?', 'sure', 'it's my turn', 'here you are' (Paul, 2007; Phillips, 1993; Pinter, 2006). Ungkapan ungkapan tersebut dapat digunakan dalam rutinitas selama proses pembelajaran agar anak semakin terbiasa.

Dari penjelasan tersebut, dapat disimpulkan bahwa penggunaan bahasa Inggris sebagai bahasa pengantar sangat dianjurkan terutama dalam konteks EFL. Hal itu dilakukan agar anak mendapat exposure tehadap bahasa Inggris semaksimal mungkin selama proses pembelajaran. Pernyataan tersebut didukung oleh para ahli pembelajaran EFL untuk anak (Brewster et al., 2002; Paul, 2007; Pinter, 2006; Phillips, 1993). Sekaitan dengan penggunaan bahasa target sebagai bahasa pengantar, penelitian yang dilakukan Coyne, McCoach, Loftus, Zipoli Jr., \& Kapp (2009) merekomendasikan guru untuk agar tidak terlalu sering menjelaskan arti kata dalam proses mendongeng karena hal tersebut akan membuat anak terdistraksi dari jalan cerita yang ada pada dongeng. Dengan demikian seorang guru sebaiknya yakin akan kemampuan anak untuk dapat memahami suatu makna yang terkandung dalam bahasa Inggris walaupun tidak memahami arti kata per kata (Halliwell, 1994; Moon, 2005; Pinter, 2006). 
Walaupun penggunaan bahasa Inggris secara penuh sebagai bahasa pengantar di kelas EFL sangat dianjurkan, ada beberapa situasi ketika penggunaan bahasa Indonesia tidak dapat dihindarkan. Moon (2005, hlm. 66) mengidentifikasi situasi tersebut sebagai berikut:

1. Ketika anak merasa sedih atau marah. Dalam situasi ini guru dapat menggunakan bahasa Indonesia untuk menunjukkan rasa simpati dan kedekatan dengan anak.

2. Ketika anak mengetahui jawaban atas pertanyaan guru, namun tidak dapat mengungkapkannya dalam bahasa Inggris. Situasi ini membolehkan anak untuk mengungkapkan jawaban dalam bahasa Indonesia, untuk kemudian guru dapat melakukan recasting agar anak mengetahui cara mengungkapkannya dalam bahasa Inggris.

3. Ketika anak ingin bercerita tentang pengalamannya namun bahasa Inggrisnya masih terbatas. Dalam situasi ini anak dapat berbagi pengalaman dalam bahasa Indonesia.

4. Ketika anak maupun guru ingin berkelakar/bercanda. Alasan digunakannya bahasa Indonesia dalam situasi ini adalah untuk membangun kedekatan guru anak. Selain itu hal ini dapat dilakukan ketika bahan candaan tidak ada padanannya dalam bahasa Inggris.

5. Ketika guru ingin mengenalkan suatu permainan baru yang memiliki aturan rumit. Penjelaan guru tentang aturan yang berlaku dapat disampaikan dalam bahasa Indonesia. Hal yang terpenting adalah anak berlatih berbahasa Inggris ketika proses permainan berlangsung.

6. Ketika guru merasa tidak yakin apakah anak telah paham atau tidak. Guru dapat memastikannya dengan bertanya langsung pada anak dalam bahasa Indonesia.

7. Ketika guru ingin anak untuk mengetahui berbagai strategi belajar bahasa Inggris. Guru dapat membantu anak untuk menguasai suatu ungkapan bahasa Inggris dengan diberi bantuan instruksi dalam bahasa Indonesia.

\section{PENUTUP}

Dari penjelasan tersebut dapat diketahui bahwa guru dianjurkan untuk selalu menggunakan bahasa Inggris selama proses pembelajaran dan pengenalan bahasa Inggris untuk anak usia dini. Terlebih lagi dalam konteks EFL dimana exposure bahasa Inggris yang didapatkan anak di luar kelas sangatlah terbatas. Untuk mengatasi kendala keterbatasan kemampuan bahasa Inggris, guru dianjurkan untuk senantiasa meningkatkan kemampuan bahasa Inggris dengan terus belatih. Namun guru juga seyogianya perlu mengetahui situasi tertentu dimana penggunaan bahasa Indonesia diperlukan. Tentu saja keputusan menggunakan bahasa Indonesia di kelas EFL memerlukan pertimbangan yang menyeluruh dan bijaksana. 


\section{DAFTAR PUSTAKA}

Ananthia, W. (2010). Storytelling in an Indonesian Primary School EFL Context: Teachers Perspectives. Unpublished Master Thesis. Melbourne: Monash University.

Ananthia, W., Harun, C. A. \& Silawati, E. (2015). The analysis of teacher's talk in teaching English to children at Indonesian kindergarten. Proceeding. Makalah disajikan pada Seminar Tahunan Linguistik (SETALI) 4-5 Juni 2015, Bandung.

Brewster, J., Ellis, G., \& Girard, D. (2002). The Primary English Teacher's Guide. London: Penguin.

Cameron, L. (2001). Teaching language to young learners. Cambridge: Cambridge University Press.

Coyne, M. D., McCoach, D. B., Loftus, S., Zipoli Jr., R., \& Kapp, S. (2009). Direct vocabulary instruction in kindergarten: Teaching for breadth versus depth. The Elementary School Journal. Vol 110(1) page 1-18. The University of Chicago.

Halliwell, S. (1994). Teaching English in the primary classroom. New York: Longman Publishing.

Harun, C. A., Yuliariatiningsih, S.Y., Ananthia, W. \& Yanthi, N. (2014). Metode permainan untuk mengembangkan penguasaan kosakata Bahasa Inggris dan keterampilan proses sains anak usia dini. Laporan penelitian yang tidak diterbitkan. Bandung: Universitas Pendidikan Indonesia.

Linse, C. (2005). Practical English language teaching: Young learners. New York: McGraw-Hill.

Moon, J. (2005). Children learning English: A guidebook for English language teachers. London: Macmillan Publishers Limited.

Paul, D. (2007). Teaching English to children in Asia. Quarry Bay: Pearson Lingman Asia ELT.

Phillips, S. (1993). Young learners. Oxford: Oxford University Press.

Pinter, A. (2006). Teaching young language learners. Oxford: Oxford University Press.

Scott, W. A. \& Ytreberg, L. H. (2003). Teaching English to children. New York: Longman.

Yuliariatiningsih, S.Y., Ananthia, W. \& Yanthi, N. (2013). The application of picture-mapping method in storytelling to develop young learners' English Mastery. International Journal of Teacher Education UPSI-UPI, 1, page 104-109. 